\title{
IMPLEMENTASI WEB PUSH NOTIFICATION PADA SISTEM INFORMASI MANAJEMEN ARSIP MENGGUNAKAN PUSHJS
}

\author{
Alam Rahmatulloh', Andi Nur Rachman², Fahmi Anwar ${ }^{3}$ \\ 1,2,3 Jurusan Informatika, Fakultas Teknik, Universitas Siliwangi \\ Email: 1alam@unsil.ac.id, ${ }^{2}$ andy.rachman@unsil.ac.id, ${ }^{3}$ fahwar95@gmail.com
}

(Naskah masuk: 17 Juli 2018, diterima untuk diterbitkan: 13 Februari 2019)

\begin{abstract}
Abstrak
Teknologi terus menerus berkembang, berbagai jenis teknologi terus bermunculan seperti sistem informasi manajemen arsip, masalahnya para pekerja kadang melakukan pekerjaan lain di komputer sehingga arsip tidak terkontrol. Penerapan Web Push Notification dapat menampilkan pemberitahuan berbasis website meskipun tidak membuka web browser secara langsung atau dalam kondisi minimize. Web Push Notification merupakan mekanisme pemberitahuan menggunakan Javascript pada web browser. Fitur ini tersedia dalam Push API HTML5 dengan menggunakan Push Service atau Messaging server yang mengirim pemberitahuan ke web browser yang telah berlangganan tanpa membuka website sehingga dapat melakukan broadcast message dan Notification API HTML5 tidak memerlukan Push Service atau Messaging server tetapi harus membuka website, tetapi belum didukung semua web browser sehingga pada makalah ini dibahas Implementasi Web Push Notification pada sistem informasi manajemen arsip menggunakan PushJS, metode pengembangan yang digunakan adalah Rational Unified Proccess (RUP). Teknologi pemberitahuan yang cocok untuk sistem informasi manajemen arsip berbasis web yaitu Notification API HTML5 karena tidak akan mengirim pemberitahuan yang sama ke semua pengguna. Namun tidak ada proses di belakang layar sehingga tidak akan dijalankan secara otomatis, masalah tersebut diatasi dengan menggunakan $A J A X$ dengan mengambil JSON kemudian dijalankan berulang-ulang pada web browser dan meminimalisir bentrokan antara script web push notification di multi tab window atau window web browser diatasi menggunakan localStorage dari WebStorage API HTML5. Hasil uji menunjukan bahwa penerapan teknologi Web Push Notification pada Sistem Informasi Manajemen Arsip dapat membantu para pengguna dalam mengelola arsip yang banyak serta penggunaan $A J A X$ berpengaruh terhadap kecepatan akses web.
\end{abstract}

Kata kunci: ajax, json, notification api html5, pushjs, webstorage api html5

\section{APPLIED WEB PUSH NOTIFICATION USES PUSH JS IN THE ARCHIVE MANAGEMENT INFORMATION SYSTEM}

\begin{abstract}
Technology continues to evolve, various types of technology continue to emerge such as records management information systems, the problem is that workers sometimes do other work on the computer so that the archive is not controlled. Web Push Notification application can display website-based notifications even if you don't open the web browser directly or in a minimized condition. Web Push Notification is a notification mechanism using Javascript in a web browser. This feature is available in the HTML5 Push API by using a Push Service or Messaging server that sends notifications to subscribed web browsers without opening the website so that it can broadcast and the HTML5 Notification API does not require a Push Service or Messaging server but must open a website, but not supported all web browsers so that this paper discusses Push Notification Web Implementation in archive management information systems using PushJS, the development method used is the Rational Unified Process (RUP). Notification technology that is suitable for web-based archive management information systems namely HTML5 Notification API because it will not send the same notification to all users. But there is no process behind the scenes so that it will not be run automatically, the problem is overcome by using AJAX by retrieving JSON and then running repeatedly on the web browser and minimizing clashes between web push notification scripts on multi tab windows or web browser windows resolved using localStorage from the HTML5 WebStorage API. The test results show that the application of Web Push Notification technology in the Archive Management Information System can help users manage many archives and use AJAX influences the speed of web access.
\end{abstract}

Keywords: ajax, json, notification api html5, pushjs, webstorage api html5 


\section{PENDAHULUAN}

Pada umumnya sebuah aplikasi berbasis web tidak mempunyai fasilitas notifikasi atau pemberitahuan terbaru kepada pengguna, sehingga proses penyampaian informasi terutama informasi penting tidak diketahui secara langsung. Hal tersebut tentunya menjadi permasalahan, terutama pada sistem informasi manajemen arsip yang memerlukan penanganan yang cepat terhadap informasi arsip yang baru masuk. Jika tidak segera ditangani arsip terus bertumpuk dan semakin banyak, sementara pengguna aplikasi atau petugas tidak mungkin terus standby memperhatikan aplikasi manajemen arsip. Permasalahan tersebut dapat diatasi dengan menerapkan sistem notifikasi secara otomatis tanpa harus membuka atau memperhatikan aplikasi terus menerus. Teknik-teknik dalam penyajian data secara realtime yang telah dilakukan pada aplikasi web diantaranya dapat menggunakan Asynchronous Javascript and XML (AJAX) dan Web Socket (Husen, 2018).

Bentuk pemberitahuan saat ini yang sedang tren yaitu pemberitahuan pada header halaman web (Bahtiar \& Mulwinda, 2016) dengan menggunakan AJAX atau sejenisnya namun pemberitahuan ini hanya dapat terlihat ketika membuka halaman web secara langsung. Pemberitahuan pada perangkat Android menggunakan Google Cloud Messaging (GCM) dengan menerapkan Calendar Provider. Calendar Provider merupakan jenis data yang dapat digunakan pada aplikasi kalender di perangkat Android (Setiawan, 2015) namun jenis pemberitahuan ini hanya berjalan pada perangkat Android dan GCM jika diterapkan pada web hanya dapat digunakan pada Push API dengan jenis pesan yang dikirim secara masal apabila telah berlangganan. Pemberitahuan pada perangkat Android dengan konsep alarm jadwal perkuliahan (Ramadhan \& Utomo, 2014). Pemberitahuan monitoring menggunakan SMS Gateway (Fiade, et al., 2013) atau sistem pemilihan umum menggunakan SMS Gateway (Satrio, dkk., 2018) namun pemberitahuannya menggunakan biaya SMS. Adapun pemberitahuan menggunakan email (Asri, 2014).

Sementara pada penelitian Rosidin menyatakan bahwaWeb Push Notification merupakan teknologi pemberitahuan yang harus diterapkan pada web masa kini (Rosidin, 2017). Sehingga fokus penelitian ini, untukmendukung teknologi informasi dalam pengiriman informasi pemberitahuan yang terkontrol dibutuhkan implementasi Web Push Notification pada Sistem Informasi Manajemen Arsip menggunakan PushJS, karena fitur teknologi Push API HTML5 dan Notification API HTML5 belum didukung oleh semua web browser sehingga menggunakan PushJS sebagai library pada lintas platform (Nickerson, 2017).

\section{WEB PUSH NOTIFICATION}

Web Push Notification merupakan pemberitahuan yang dapat dikirim ke pengguna melalui web desktop dan web seluler. Pemberitahuan ini merupakan pesan gaya lansiran yang tampil pada sudut kanan atas atau bawah layar desktop, tergantung pada sistem operasi, atau muncul di perangkat seluler dengan cara yang hampir identik dengan Push Notification yang dikirim dari aplikasi. Web Push Notification dikirimkan di desktop atau layar seluler pengguna kapan pun ketika web browser dijalankan meskipun pengguna membuka halaman web atau tidak (Urbanairship, 2018).

\subsection{Push APIHTML5}

Push APIHTML5 merupakan jenis notifikasi pada web browser yang menggunakan Push Service atau Messaging server sebagai tempat broadcast messaging dengan syarat web browser telah berlangganan (Ater, 2017). Push APIHTML5 memungkinkan pengiriman pesan push ke webapp melalui layanan push. Server dapat mengirim pesan push kapan saja, bahkan ketika webapp atau user agent tidak aktif. Layanan push memastikan pengiriman yang andal dan efisien kepada agen pengguna. Pesan push dikirim ke Service Worker yang berjalan di webapp, yang dapat menggunakan informasi dalam pesan untuk memperbarui status lokal atau menampilkan pemberitahuan kepada pengguna. Push API memungkinkan webapp untuk berkomunikasi dengan user agent secara asinkron. Ini memungkinkan server aplikasi untuk memberikan informasi kapan tanpa membuka webapp (W3C, 2017).

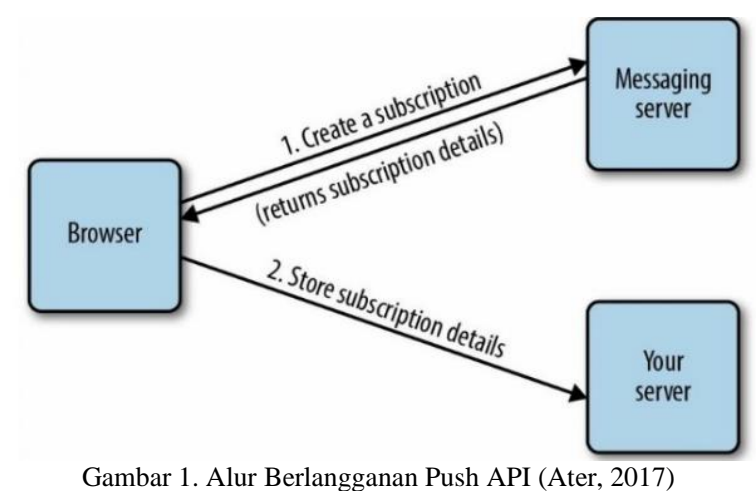

Gambar 1 merupakan alur dalam penggunaan pertama Push API dengan memanggil subscriber(). Pusat server perngiriman pesan akan menyimpan rincian langganan baru ini dan mengembalikan ke halaman, selanjutnya halaman dapat mengirim rincian berlangganan ke server dimana data disimpan untuk digunakan. 


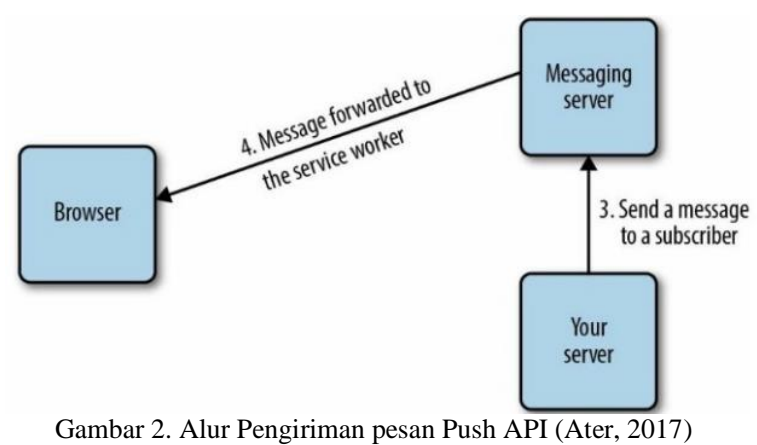

Gambar 2 merupakan alur pengiriman Push API dengan memanfaatkan rincian langganan dengan mengirim pesan ke message server kemudian meneruskan ke web browser pengguna, pada saat itu ServiceWorker bekerja apabila telah terdaftar di web browser.

\subsection{Notification API HTML5}

Notification API HTML5 memungkinkan halaman web atau pekerja layanan (service worker) untuk membuat dan mengontrol tampilan pemberitahuan sistem. Pemberitahuan ini ditampilkan di luar web browser (di antarmuka perangkat) dan dengan demikian ada di luar konteks jendela atau tab web browser tunggal. Karena tidak bergantung pada jendela atau tab peramban apa pun, mereka dapat dibuat bahkan setelah pengguna meninggalkan situs. Sebelum dapat menampilkan pemberitahuan kepada pengguna, pengguna harus terlebih dahulu meminta izin pengguna. Keseluruhan prosesnya relatif sederhana dan lugas (Ater, 2017).

Notification API untuk menampilkan pemberitahuan untuk memperingatkan pengguna di luar konteks halaman web. Pemberitahuan ini mengacu pada menampilkan pemberitahuan pada "desktop". ini dirancang agar kompatibel dengan platform pemberitahuan yang ada sebanyak mungkin, tetapi juga menjadi platform-independen. Karena platform umum tidak menyediakan fungsi yang sama, spek ini akan menunjukkan peristiwa apa yang dijamin dan mana yang tidak. Khususnya, pemberitahuan yang ditentukan di sini hanya dapat berisi konten teks dan ikon (W3C, 2015).

\subsection{PushJS}

PushJS adalah salahsatu cara untuk membangun dan menjalankan pemberitahuan desktop Javascript. Tambahan yang cukup baru untuk spesifikasi resmi, NotificationAPI memungkinkan browser modern seperti Chrome, Safari, Firefox, dan IE 9+ untuk mendorong pemberitahuan ke desktop pengguna. PushJS bertindak sebagai solusi lintas peramban untuk API ini, fallback menggunakan penerapan yang lebih lama jika peramban pengguna tidak mendukung API baru (Nickerson, 2017).

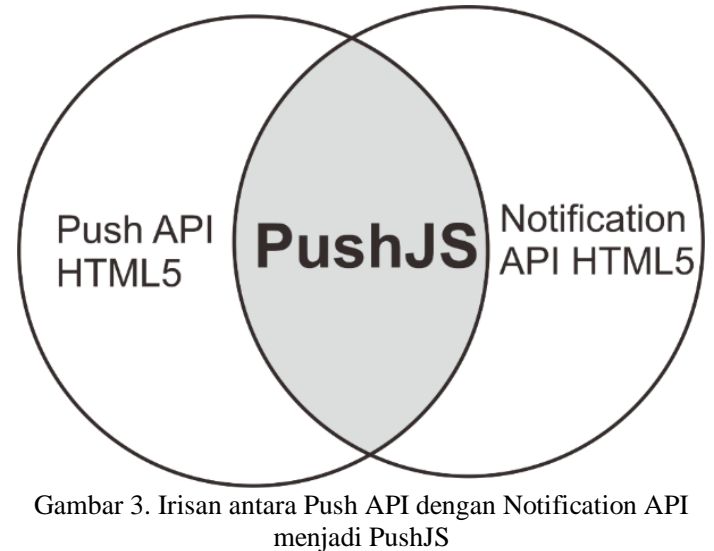

Gambar 3 merupakan perumpamaan bahwa PushJS memiliki kemampuan dari Push API HTML5 dan Notification API HTML5. Fungsi utama notifikasi menggunakan Notification API HTML5 dan menggunakan serviceWorker untuk menggunakan teknologi Push API HTML5 sehingga tidak langsung menggunakan fasilitas dari Web Browser.

\subsection{WebStorage API HTML5}

Web Storage API HTML5 atau disebut DOMStorage merupakan sebuah API yang membuatnya mudah untuk menyimpan data di seluruh web. Sebelum ada Web Storage API, remote server diperlukan untuk menyimpan data apa pun yang bertahan dengan mengirimnya bolak-balik dari klien ke server. Dengan munculnya Web Storage API, pengembang sekarang dapat menyimpan data secara langsung di sisi klien pada web browser untuk akses berulang di seluruh permintaan atau untuk diambil secara lama setelah menutup browser sepenuhnya, sehingga mengurangi lalu lintas jaringan. Web Storage berbeda dari cookie dari bagaimana cara menyimpan dan mengambil data. Dengan menggunakan API sederhana ini, pengembang dapat menyimpan nilai dalam objek JavaScript yang mudah diambil yang bertahan di seluruh beban halaman. Dengan menggunakan sessionStorage atau localStorage, pengembang dapat memilih untuk membiarkan nilai-nilai tersebut bertahan baik di seluruh beban halaman dalam satu jendela atau $t a b$ atau di seluruh browser saat di restart. Data yang tersimpan tidak ditransmisikan di seluruh jaringan dan mudah diakses pada kunjungan kembali ke halaman (Ater, 2017).

\subsection{PHP Data Objects}

PDO (PHP Data Objects) merupakan fitur PHP yang telah ada mulai versi 5. PDO merupakan jenis salah satu teknik penggunaan database dengan satu query yang sama tanpa mengubah script hanya mengatur koneksi tujuan database engine, karena mendukung berbagai jenis database, dimana untuk untuk memanggil seluruh fungsi setiap database tidak 
memperlukan perubahan script pada fungsi koneksi ke database. PDO juga mendukung $S Q L$ injectiondengan menerapkan PDO BlindParam statement parameter ataumasukan dari pengguna secara otomatis telah di saringterlebih dahulu sebelum diproses. PDO menggunakan teknologi data-access abstaction layer untuk menghungkan script dengan database.PDO memiliki beberapa keuntungan, diantaranya (Abdul, 2008):

1. PDO mendukung banyak database, database yang didukung oleh PDO antara lain MySQL, PostgreSQL, Oracle, SQLite, IBM, Firebird, $D B L i b$ dan lain-lain.

2. PDO dapat melakukan migrasi databaseengine yang digunakan karena dalam PDO query setiap database engine tetap sama yang membedakannya hanyalah koneksi.

PDO juga memiliki beberapa kelemahan, diantaranya:

1. PDO tidak dapat menggunakan beberapa fitur canggih dari database engine yang digunakan, seperti dukungan eksekusi Multiple Statements di MySQL.

2. PDO tidak bisa menggunakan sintaks SQL yang spesifik untuk database tertentu, seperti CTE atau Common Table Expression, yang telah didukung databasedari Oracle dan PostgreSQL.

\section{METODE PENELITIAN}

Metodologi pengembangan perangkat lunak pada penelitian ini menggunakan RUP (Rational Unified Process)mulai dari tahapan Inception (Permulaan), Elaboration (Perencanaan), Contruction (Kontruksi) dan Transition (Transisi).Proses pengulangan atau iteratif pada $R U P$ secara global dapat dilihat pada Gambar 4.

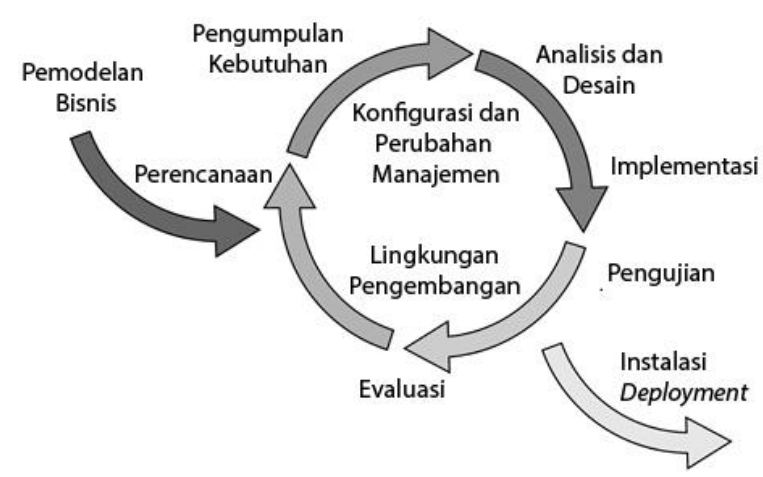

Gambar 4. Proses Iterasi RUP (Sukamto \& Shalahuddin, 2013)

\section{HASIL DAN PEMBAHASAN}

\subsection{Tahap Inception (Permulaan)}

Proses bisnis yang akan diterapkan pada Sistem Informasi Manajemen Arsip hanya pada bagian
Petugas Perpus dan Admin setelah login. Sistem yang diimplementasikan berupa pemberitahuan menggunakan PushJS, JQuery dan AJAX dengan bentuk pertukaran data menggunakan JSON. Pertukaran data JSON dapat diamankan menggunakan JSON Web Token (JWT) (Rahmatulloh, et al., 2018).

Gambar 5 merupakan rancangan usulan push notification menggunakan PushJS berbasis Javascript. Setelah melakukan login, web browserakan menjalankan script dengan mengecek status tab window atau window web browser primer atau sekunder, dilihat dari waktu pembuatan tab window atau window dalam satuan milisecond atau biasa disebut timestamp disimpan dalam localStorage menggunakan Web Storage API HTML5.

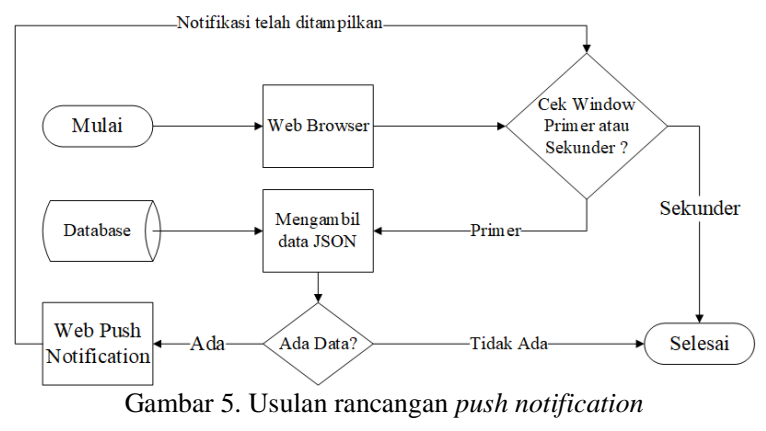

Apabila status tab window atau window primer maka akan menjalankan script pengambilan data berbentuk JSON menggunakan AJAX jika ada maka akan ditampilkan sedangkan jika tidak ada atau sudah semua data maka akan kembali lagi ke proses pengecekan status tab window atau window web browser yang digunakan.

Aktor-aktor yang berhubungan dengan sistem informasi manajemen arsip, diantaranya: Petugas SKPD (Satuan Kerja Pemerintah Daerah), Petugas DISPERPUSKA dan Pengunjung. Kebutuhan fungsional sistem informasi manajemen arsip adalah Manajemen Arsip, Manajemen Instansi, Manajemen Pengguna, Manajemen Ruangan, Manajemen Rak, Manajemen Box, Manajemen Surat, ScannerBox dan Pencarian Arsip. Kebutuhan non fungsional sistem informasi manajemen arsip adalah sistem notifikasi pemberitahuan yang bisa memberikan informasi atau pengingat ketika tanpa harus memperhatikan aplikasi atau sedang mengerjakan aktifitas lain di komputer.

\subsection{Tahap Elaboration (Perencanaan)}

Pada tahap kedua ini proses perencanaan dimulai dari menganalisa, identifikasi dan evaluasi proses bisnis yang sedang berjalan. Sehingga akan didapatkan solusi alternatif yang mengarah kepada perbaikan dan pengembangan yang lebih baik serta sesuai dengan kebutuhan.

Sistem yang sedang berjalanharus diketahui dan dipelajari terlebih dahulu, diperlukan penggambaran aliran informasi dari berbagai bagian yang terkait 
sistem. Aliran informasi yang sedang berjalan pada sistem manajemen arsip adalah sebagai berikut:

1. SKPD/Kecamatan menyerahkan Arsip untuk di dititipkan di depo arsip.

2. DIPERPUSKA menerima Arsip dari SKPD/Kecamatan yang akan ditipkan di depo arsip.

3. DIPERPUSKA menyeleksi Arsip yang akan dititipkan

4. DIPERPUSKA membuat Jadwal Resensi Arsip (JRA).

\subsection{Tahap Construction (Kontruksi)}

Implementasi sistem menggunakan PushJS ke dalam Sistem Informasi Manajemen Arsip digabungkan dengan Javascript, JQuery, AJAX, WebStorage API HTML5. Konsep pemberitahuan yang digunakan seperti runningtext pada channel televisi yang memberikan informasi terus menerus sampai informasi tersebut di ubah oleh operator. Konsep ini pula menjadi inspirasi untuk diimplementasikan pada Sistem Informasi Manajemen Arsip yang dapat memberikan pemberitahuan terus menerus sampai ditindak lanjutioleh pengguna. Pemberitahuan yang dimunculkan pada Web Push Notification seperti Arsip yang belum diatur JRA dan Arsip yang sudah melewati masa Inaktif harus ditindak sesuai jenis Arsip.

Konsep teknis yang digunakan Javascript mengecek ketersediaan web dibuka di tab window yang masa saja, kemudian script Web Push Notification akan berjalan pada tab window yang terakhir dibuka berdasarkan waktu pembuatan tab window menggunakan localStorage dan sessionStorage dari Web Storage API HTML5. Setelah itu script Web Push Notification yang menggunakan PushJS akan mengambil data berbentuk JSON dari database dengan menggunakan $A J A X$ secara realtime dan dihitung jumlah data yang akan di munculkan pada pemberitahuan dengan nilai timeout atau waktu tampil yang telah ditentukan. Apabila ada perubahan dalam pemberitahuan akan di eksekusi pada saat element data yang terakhir telah dimunculkan Gambar 6 merupakan tampilan dari antarmuka Web Push Notification.

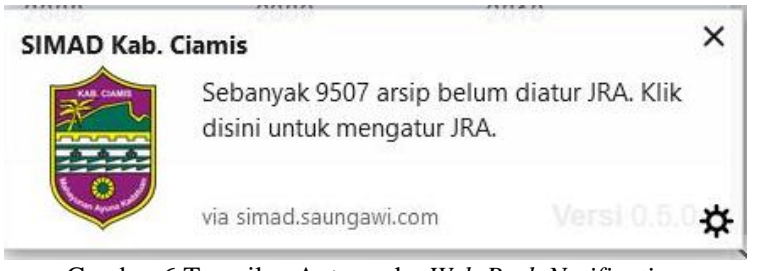

Gambar 6 Tampilan Antarmuka Web Push Notification

\subsection{Tahap Transition (Transisi)}

Sebelum proses transisi, pengujian merupakan hal terpenting yang harus dilakukan untuk mengetahui kekurangan atau kesalahan yang ada. Pengujian dilakukan dengan pengecekan secara fungsional (black box). Pada proses pengecekan menggunakan localStorage menghasilkan timestamp dalam format milisecond atau milidetik kemudian dibandingkan waktu yang paling terbaru membuat window atau $t a b$ window pada web browser dengan menghasilkan data berbentuk JSON seperti pada Gambar 7 bernilai [“1528123760571","1528123775172"] yang berarti 06-04-2018 14:49:20 dan 06-04-2018 14:49:35 pada zona Universal TimeCoordinated (UTC) sedangkan Asia/Jakarta ditambah 7 jam lebih cepat. Jadi, tab window atau window yang akan menjalankan web push notification yang dibuat pada 1528123775172 atau 06-04-2018 14:49:35 pada zona UTC.

Value

\section{["1528123760571","1528123775172"]}

Gambar 7. Isi data localStorage menggunakan Inspect Element pada Web Browser

Pengujian selanjutnya uji fungsional sistem menggunakan skenario uji yang hasilnya dapat dilihat pada Tabel 1.

\begin{tabular}{|c|c|c|c|}
\hline \multicolumn{4}{|c|}{ Tabel 1 Bagian Uji Fungsional Sistem } \\
\hline $\begin{array}{c}\text { Nama } \\
\text { Bagian }\end{array}$ & $\begin{array}{c}\text { Skenario } \\
\text { Uji }\end{array}$ & $\begin{array}{c}\text { Hasil yang } \\
\text { diharapkan }\end{array}$ & Kesimpulan \\
\hline \multirow{4}{*}{$\begin{array}{c}\text { Web Push } \\
\text { Notification }\end{array}$} & $\begin{array}{l}\text { Belum } \\
\text { melakukan } \\
\text { Login }\end{array}$ & $\begin{array}{l}\text { Tidak } \\
\text { menampilkan } \\
\text { pemberitahuan }\end{array}$ & $\begin{array}{l}{[\sqrt{ }] \text { Berhasil }} \\
{[\text { ] Tidak }} \\
\text { Berhasil }\end{array}$ \\
\hline & $\begin{array}{l}\text { Setelah } \\
\text { Pengguna } \\
\text { Login } \\
\text { (Petugas } \\
\text { Perpus) }\end{array}$ & $\begin{array}{l}\text { Menampilkan } \\
\text { pemberitahuan }\end{array}$ & $\begin{array}{l}{[\sqrt{ }] \text { Berhasil }} \\
{[\text { Tidak }} \\
\text { Berhasil }\end{array}$ \\
\hline & $\begin{array}{l}\text { Setelah } \\
\text { Pengguna } \\
\text { Login } \\
\text { (Petugas } \\
\text { SKPD) }\end{array}$ & $\begin{array}{l}\text { Tidak } \\
\text { Menampilkan } \\
\text { pemberitahuan }\end{array}$ & $\begin{array}{l}{[\sqrt{ }] \text { Berhasil }} \\
{[\text { ] Tidak }} \\
\text { Berhasil }\end{array}$ \\
\hline & $\begin{array}{l}\text { Membuka } \\
\text { web di } t a b \\
\text { window } \\
\text { yang lain }\end{array}$ & $\begin{array}{l}\text { Tidak terjadi } \\
\text { bentrok script } \\
\text { yang berjalan }\end{array}$ & $\begin{array}{l}{[\sqrt{ }] \text { Berhasil }} \\
\text { [ ] Tidak } \\
\text { Berhasil }\end{array}$ \\
\hline
\end{tabular}

Dalam memproses script Web Push Notification, web browser membutuhkan beberapa detik untuk membuka halaman setelah selesai dengan pengecekan validasi window selama $1.000 \mathrm{~ms}$ (milisecond) atau 1 detik dan menampilkan notifikasi selama $5.000 \mathrm{~ms}$ (milisecond) atau 5 detik. Jadi, jika ada 10 notifikasi maka dibutuhkan waktu $5 \times 10=50$ detik untuk menampilkan semua pemberitahuan. Proses tersebut belum termasuk lama proses membuka halaman web dan data JSON.

Gambar 8 menunjukan hasil analisa menggunakan Inspect Element pada web browser Mozilla Firefoxdiperoleh 1.725 milisecond $(\mathrm{ms})$ atau 1,7 second. 


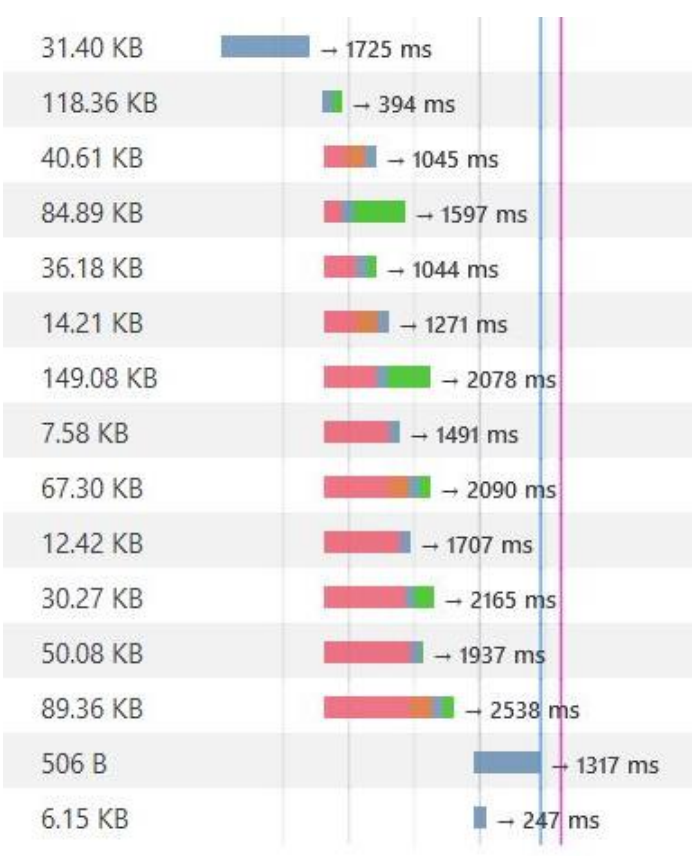

Gambar 8. Tampilan Visual Lama Waktu Proses

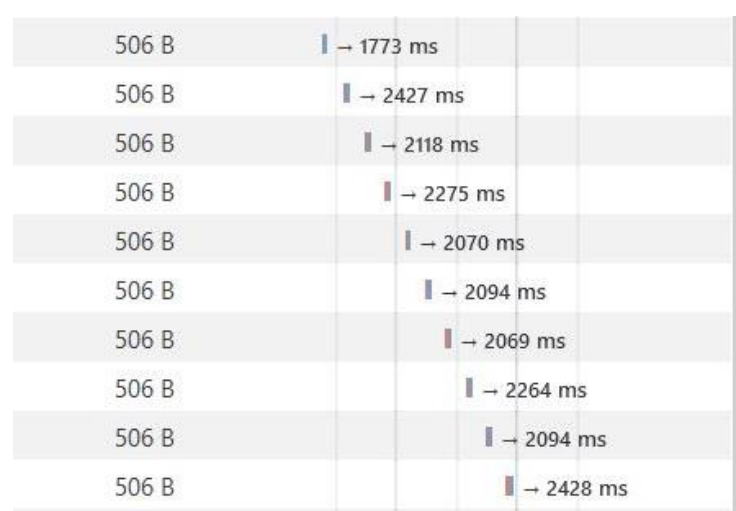

Gambar 9. Proses Pengulangan pengambilan JSON

Berdasarkan Gambar 9 diperoleh 10 sampel kemudian dimasukan kedalam Tabel 2 dengan dihitung rata-rata lama waktu pemrosesan dengan karakteristik 9.500 data arsip pada database dengan hasil compressing menjadi 506 Bytes. Hasil rata-rata diperoleh 2.161,2 milidetik yang dapat dilihat pada Tabel 2.

Tabel 2. Uji Waktu Pemrosesan Data JSON

\begin{tabular}{cc}
\hline No & $\begin{array}{c}\text { milisecond } \\
(\boldsymbol{m} \boldsymbol{)})\end{array}$ \\
\hline 1 & 1.773 \\
2 & 2.427 \\
3 & 2.118 \\
4 & 2.275 \\
5 & 2.070 \\
6 & 2.094 \\
7 & 2.069 \\
8 & 2.264 \\
9 & 2.094 \\
10 & 2.428 \\
\hline Jumlah & 21.612 \\
Rata-rata & $2.161,2$ \\
\hline
\end{tabular}

\section{1. webpush is function (1)}

1. webpush is function!

Source: @http://localhost/qunit.html:15:7

2. webpush exist (1)

1. webpush exist!

Source:@http://localhost/qunit.html:18:5

Gambar 10 Unit Testing Web Push Notificationmenggunakan QUnit

Gambar 10 merupakan hasil unit testing Web Push Notification menggunakan QUnit menunjukan fungsi webpush() pada HTML berjalan sesuai dengan harapan.

\begin{tabular}{cl} 
& \multicolumn{1}{c}{ Tabel 3. Bagian Pernyataan Pengujian Beta } \\
\hline No. & \multicolumn{1}{c}{ Pernyataan } \\
\hline 1 & $\begin{array}{l}\text { Kesesuaian warna tulisan dengan warna latar belakang } \\
\text { (background) pop-up pemberitahuan }\end{array}$ \\
\hline 2 & Tulisan pada pop-up pemberitahuan terbaca \\
\hline 3 & Tampilan kotak pop-up pemberitahuan terlihat jelas \\
\hline 4 & $\begin{array}{l}\text { Penggunaan pop-up pemberitahuan mudah digunakan } \\
\text { saat membuka aplikasi lain }\end{array}$ \\
\hline 5 & $\begin{array}{l}\text { Ketepatan lama waktu menampilkan pop-up } \\
\text { pemberitahuan }\end{array}$ \\
\hline
\end{tabular}

Tabel 3 merupakan pernyataan yang digunakan pada pengujian User Acceptance Testing (UAT) pada 5 reponden menghasilkan persentase nilai kepuasan dalam penggunaan aplikasi yang telah diterapkan teknologi Web Push Notification dengan 5 pilihan seperti pada Tabel 4.

Tabel 4. Skor Jawaban Kuesioner

\begin{tabular}{ccc}
\hline $\begin{array}{c}\text { Skala } \\
\text { Jawaban }\end{array}$ & Keterangan & Skor \\
\hline SS & Sangat Setuju & 5 \\
S & Setuju & 4 \\
N & Netral & 3 \\
TS & Tidak Setuju & 2 \\
STS & Sangat Tidak & 1 \\
\hline
\end{tabular}

Pengujian UAT pada aplikasi setelah diterapkan teknologi Web Push Notification menghasilkan beberapa tabel berdasarkan pernyataaan, diantaranya:

1. Data Pernyataan "Kesesuaian warna tulisan dengan warna latar belakang (background) pop-up pemberitahuan" pada Tabel 5.

\section{Tabel 5. Data Pernyataan 1}

\begin{tabular}{cccc}
\hline Skala Jawaban & Skor & Responden & Jumlah \\
\hline Sangat Setuju & 5 & 3 & 15 \\
Setuju & 4 & 2 & 8 \\
Netral & 3 & 0 & 0 \\
Tidak Setuju & 2 & 0 & 0 \\
\hline
\end{tabular}




\begin{tabular}{cccc}
\hline Skala Jawaban & Skor & Responden & Jumlah \\
\hline $\begin{array}{c}\text { Sangat Tidak Setuju } \\
\text { Jumlah }\end{array}$ & 1 & 0 & 0 \\
\hline \multirow{2}{*}{$Y=\frac{23}{25} \times 100=92$} & & 23 \\
\hline
\end{tabular}

2. Tulisan pada pop-up pemberitahuan terbaca

\begin{tabular}{cccc}
\multicolumn{4}{c}{ Tabel 6. Data Pernyataan 2} \\
\hline Skala Jawaban & Skor & Responden & Jumlah \\
\hline Sangat Setuju & 5 & 1 & 5 \\
Setuju & 4 & 4 & 16 \\
Netral & 3 & 0 & 0 \\
Tidak Setuju & 2 & 0 & 0 \\
Sangat Tidak Setuju & 1 & 0 & 0 \\
Jumlah & & 5 & 21 \\
\hline \\
$\mathrm{Y}=\frac{21}{25} \times 100=84$ & &
\end{tabular}

3. Tampilan kotak pop-up pemberitahuan terlihat jelas.

Tabel 7. Data Pernyataan 3

\begin{tabular}{cccc}
\hline Skala Jawaban & Skor & Responden & Jumlah \\
\hline Sangat Setuju & 5 & 4 & 5 \\
Setuju & 4 & 1 & 16 \\
Netral & 3 & 0 & 0 \\
Tidak Setuju & 2 & 0 & 0 \\
Sangat Tidak Setuju & 1 & 0 & 0 \\
Jumlah & & 5 & 5 \\
\hline
\end{tabular}

$$
\mathrm{Y}=\frac{24}{25} \times 100=96
$$

4. Penggunaan pop-up pemberitahuan mudah digunakan saat membuka aplikasi lain.

\begin{tabular}{|c|c|c|c|}
\hline Skala Jawaban & Skor & Responden & Jumlah \\
\hline Sangat Setuju & 5 & 3 & 15 \\
\hline Setuju & 4 & 2 & 8 \\
\hline Netral & 3 & 0 & 0 \\
\hline Tidak Setuju & 2 & 0 & 0 \\
\hline Sangat Tidak Setuju & 1 & 0 & 0 \\
\hline Jumlah & & 5 & 23 \\
\hline
\end{tabular}

5. Ketepatan lama waktu menampilkan pop-up pemberitahuan.

Tabel 9. Data Pernyataan 5

\begin{tabular}{cccc}
\hline Skala Jawaban & Skor & Responden & Jumlah \\
\hline Sangat Setuju & 5 & 0 & 0 \\
Setuju & 4 & 5 & 20 \\
Netral & 3 & 0 & 0 \\
Tidak Setuju & 2 & 0 & 0 \\
Sangat Tidak Setuju & 1 & 0 & 0 \\
Jumlah & & 5 & 5 \\
\hline Y $=\frac{20}{25} \times 100=80$ & &
\end{tabular}

Hasil pengujian UAT berdasarkan rata-rata dari persentase persamaan (1), (2), (3), (4) dan (5) menghasilkan :

$\mathrm{Y}=\frac{92+84+96+92+80}{500} \times 100=89,6$
Tabel 10. Skor Jawaban Kuesioner

\begin{tabular}{ccc}
\hline $\begin{array}{c}\text { Skala } \\
\text { Jawaban }\end{array}$ & Keterangan & Nilai \\
\hline SS & Sangat Setuju & $100 \%$ \\
S & Setuju & $80 \%$ \\
N & Netral & $60 \%$ \\
TS & Tidak Setuju & $40 \%$ \\
STS & Sangat Tidak & $20 \%$ \\
\hline
\end{tabular}

Persamaan (6) mengasilkan nilai 89,6 \% mendekati skala Sangat Setuju sesuai dengan parameter pada Tabel 10, sehingga penerapan Web Push Notification berdasarkan pengujian UAT dengan 5 responden menghasilkan nilai Sangat Setuju dengan persentase $89,6 \%$.

\section{KESIMPULAN}

Penerapan Web Push Notification dalam pemberitahuan pada Sistem Informasi Manajemen Arsip dapat membantu dalam proses penyampaian informasi sehingga lebih interaktif dan realtime. Sementara penggunaan Web Storage API HTML5 berfungsi untuk mengecek status tab window pada web browser yang sama, sehingga Javascript tidak bentrok saat dijalankan pada multi tab window.

Sebagai bahan penelitian selanjutnya teknologi Web Push Notification dapat dikembangkan lebih lanjut dengan fitur input atau multiple choice sehingga pengguna dapat memasukan data langsung atau memilih opsi yang ada pada notifikasi tanpa harus membuka halaman web.PushJS dapat dikembangkan menggunakan serviceWorker dengan teknologi Push API HTML5 dengan memanfaatkan Firebase Cloud Messaging.

\section{DAFTAR PUSTAKA}

ABDUL, K., 2008. Dasar Pemrograman Web Dinamis Menggunakan PHP. 1 penyunt. Yogyakarta: Penerbit Andi.

ASRI, N. F., HAMZAH, A. \& SHOLEH, M., 2014. Nagios untuk Monitoring Server dengan Pengiriman Notifikasi Gangguan Server menggunakan Email dan SMS Gateway (Studi Kasus: PT. Gamatechno Indonesia Yogyakarta). Jurnal JARKOM, 1(2), pp. 151161.

ATER, T., 2017. Building Progressive Web Apps. 1 penyunt. Sebastopol: O'Reilly Media.

BAHTIAR, M. R. \& MULWINDA, A., 2016. Pengembangan Fitur Notifikasi pada Website Application Comic Strip rupi.co Menggunakan Metode Agile. Jurnal Teknik Elektro, 8(1), pp. 25-30.

FIADE, A., MULANA, A. A. \& SUSENO, H. B., 2013. Aplikasi Monitoring Jaringan Berbasis Mobile Web dengan Sistem Notifikasi Berbasis SMS Gateway. Jurnal Teknik Informatika, 6(2).

HUSEN, H., RAHMATULLOH, A. \& SULASTRI, H., 2018. Implementasi Komunikasi Full 
Duplex Menggunakan Sistem Informasi Pengelolaan Anggaran Universitas ABC. Simetris: Jurnal Teknik Mesin, Elektro dan Ilmu Komputer, 1 4, 9(1), pp. 597-606.

NICKERSON, T., 2017. Installing | Push v1.0. [Online]

Available

at:

https://pushjs.org/docs/introduction [Diakses 1507 2018].

RAHMATULLOH, A., SULASTRI, H. \& NUGROHO, R., 2018. Keamanan RESTful Web Service Menggunakan JSON Web Token (JWT) HMAC SHA-512. Jurnal Nasional Teknik Elektro dan Teknologi Informasi (JNTETI).

RAMADHAN, T. \& UTOMO, V. G., 2014. Rancang Bangun Aplikasi Mobile Untuk Notifikasi Jadwal Kuliah Berbasis Android (Studi Kasus: Stmik Provisi Semarang). Jurnal Teknologi Informasi dan Komunikasi, 5(2), pp. 47-55.

ROSIDIN, 2017. Manfaat Menggunakan Push Notification Untuk Website - JURNAL ROSID. [Online]

Available at: https://jurnal.rosid.net/manfaatmenggunakan-push-notification-untukwebsite/

[Diakses 1507 2018].

SATRIO, dkk., 2018. Rancang Bangun Sistem E2OV (Electronic - Election Observation and Voting) Menggunakan SMS. Jurnal Teknologi Informasi dan Ilmu Komputer, 5(1), pp. 1-6.

SETIAWAN, J., KRISTIANTO, E. \& F., 2015. Implementasi Push Notification pada Informasi Perkuliahan dan Kegiatan Mahasiswa Berbasis Android. Jurnal Teknik dan Ilmu Komputer, 4(14), pp. 211-219.

SUKAMTO, R. A. \& SHALAHUDDIN, M., 2013. Rekayasa Perangkat Lunak (Terstruktur dan Berorientasi Objek). Bandung: BI-Obses.

Urbanairship, 2018. Web Push Notifications Explained | Urban Airship. [Online] Available at: https://www.urbanairship.com/web-pushnotifications-explained [Diakses 1507 2018].

W3C, 2015. Notification API : W3C Recommendation 22 October 2015. [Online] Available at: https://www.w3.org/TR/notifications/ [Diakses 1507 2018].

W3C, 2017. Push API : W3C Working Draft. [Online] Available at: https://www.w3.org/TR/pushapi/

[Diakses 1507 2018]. 